\title{
College English Teaching in Multimedia Environment
}

\author{
Xueqin Li \\ Teaching and Research Institute of Foreign Languages, Bohai University, Jinzhou, 121013, China \\ 284554744@qq.com
}

Keywords: multimedia environment; college English teaching; advantages; problems; suggests

\begin{abstract}
College English teaching should make full use of modern information technology, the selection of excellent teaching software, to encourage teachers' effective use of network and multimedia and other teaching resources. In order to promote the application of multimedia in college English teaching, this paper analyzes on the advantages of the multimedia college English teaching, points out the problems of multimedia college English teaching and puts forward some Suggestions of multimedia college English teaching. Specific recommendations include: to realize the combination of traditional teaching method and modern teaching means, pay attention to the practicability of multimedia courseware, avoid the English course into multimedia courseware display, follow the principle of Meyer multimedia design, etc., this article research results to college English teaching can achieve the purpose of giving full play to the advantages of multimedia and reduce negative effect of multimedia.
\end{abstract}

\section{Introduction}

Multimedia is a combination of a variety of media, generally including text, voice and image, and other forms of media. In a computer system, multimedia refers to the combination of two or more media a man-machine interactive exchange of information and media. Multimedia teaching refers to the use of multimedia computer, according to the characteristics of the teaching goal and the teaching object, comprehensive treatment and control symbols, language, text, sound, graphics, images and video and other media information, the element according to the requirements of teaching, multimedia units to have passed the projector screen or projection display, according to the need to add sound to cooperate, at the same time and the human-computer interaction between the user and the computer operation, complete the teaching or training process.

The ministry of education promulgated "college English curriculum requirements", points out that the institutions of higher learning should make full use of modern information technology, based on the computer and the classroom English teaching mode, the improvement is given priority to with teachers teach single teaching mode. For the implementation of the new teaching mode and development of online teaching system should include teaching, learning, feedback, and management of whole process, including the self-assessment, teachers teaching and learning, teachers online tutoring, coaching on students' learning and teachers of monitoring management module, can record at any time, to understand and test students' learning and teachers' teaching and counselling, interactive and multimedia, easy to operate. The institutions of higher learning should choose excellent teaching software, to encourage teachers to effectively use the Internet and multimedia and other teaching resources.

Multimedia has rich teaching resources, to preserve and carry, save the lecture time, enhance the teaching effect, multiple teaching methods and teaching content vivid, etc. But the "science and technology is a double-edged sword", multi-media teaching in a huge benefits at the same time, also has brought the shortcomings, a lot of negative effects. Information technology can't replace teachers, just to replace or assist teachers completed duplicate or unable to complete work. In this paper, based on the status quo of multimedia college English teaching and English teaching experience for many years, puts forward some Suggestions for reference, to play the advantages of multimedia teaching, to reduce the negative effect of multimedia teaching, achieve the goal of improve the quality of college English teaching. 


\section{Advantages of Multimedia Application in College English Teaching}

Compared with the traditional teaching method, multimedia college English teaching has the following advantages:

(1) Create the language environment, stimulate interest in learning. Language learning environment includes places as well as tools and media of language learning. Learner language environment determines the way of learning, efficiency, and interest. English classroom teaching should be specific, vivid image, intuitive to make English learning a lively and full of attraction. Create a strong interest in let the student active participation, classroom atmosphere is the premise and guarantee arouse the students' main body participation, students in a relaxed and happy learning atmosphere to actively participate in teaching activities, and can stimulate the students' inner study requirements. English teaching of vocabulary, sentences, semantic and discourse coherence between the layers of progressive, using multimedia can stimulate students' interest and enthusiasm, to strengthen the language environment, create flexible classroom context. Through the text based on the technology of multimedia scene reappearance, vocabulary application environment simulation and team performance and knowledge contests, for students to create interactive teaching environment, such as sound, color and image.

(2) Expand capacity, improve the learning efficiency. Classroom capacity directly affects the quality of the classroom. Multimedia technology can achieve high density of knowledge, the optimization of large amount of information processing. Graphics is not language, but the more intuitive than words and images, inclusive information more than words. More advanced than graphic animation, using the words flashing, image resizing and moving, color transformation, not only the capacity is bigger, faster and better effect, increased the density of teaching. In the demonstration process, the teacher can demonstrate speed control, either for new knowledge, and can review the consolidation; Save a lot of blackboard writing time, avoid the traditional blackboard writing, teachers in teaching students to wait. The use of multimedia, and active classroom atmosphere, students' horizons effectively, attention highly concentrated and explore corretly ability, inspire the students' initiative and innovation ability.

(3) Expand cultural knowledge, strengthen language understanding. Language as the carrier of culture and the circulating medium is the external manifestation of culture and a kind of specific national culture contains all forms of abstract language system, in the process of the development of culture, and at the same time of the different language get development, language and culture are interdependent and influence each other and common development. Deeply understand the relationship between language and cultural relations can help foreign language learning, only by constantly to understand the culture of the target language countries or regions can really grasp and use of a language. The application of multimedia in the teaching, make students exposed to more real and broad knowledge of cultural background, from the narrow classroom space to rich multimedia world, develop the comprehensive language using ability.

(4) Training observation ability, promote the innovative thinking. Multimedia technology in English teaching for the students is to create a broad visual space. A large number of graphic information, colorful picture fully mobilize the students' vision, inspired students habits of earnest observation, cultivate the students' ability of observation. Students watch carefully, feeling rich, to the text understanding is deep and language expression ability. Use of multimedia technology, vivid, informative, interactive features, teachers can complement appropriately according to the teaching material content data, further broaden the students' thinking space, and long-term persistence to organize students to discuss, to cultivate students' divergent thinking and creative thinking.

\section{Problems of Multimedia Application in College English Teaching}

Multimedia college English teaching, in effect at the same time, also appeared a lot of problems, a brief analysis is as follows:

(1) One-sided pursuit of technical skills, ignoring the advanced teaching ideas and teaching mode and teaching is the teaching activity expression of the inherent law of subjective 
understanding, is engaged in the teaching activities of the guiding ideology and action guide. Advanced English course education concept, we should set up take the student as the guiding ideology, promote student participation, experience, practice, independent thinking and cooperative exploration. The English curriculum orientation in an open system needs reality and life. But a lot of English teachers in the process of making multimedia courseware, one-sided pursuit of technical content, spend a lot of time, that make the software more advanced, advanced technology, the more the better, to make the courseware more beautiful, more attractive, the better, the multimedia courseware as their work of art. Behind, low level of teachers education thoughts, no matter how advanced the technology to carry out teaching, also will not achieve good effect.

(2) Strong sensory stimulation, limiting the student abstract thinking ability. Abstract thinking is the people in the know using the form of thinking of concept, judgment and reasoning, to indirect generalization and reflection of the objective reality of process. College students have accumulated a certain life experiences, have mastered certain mathematical tools, have a certain ability to analyze problems, therefore, university education should focus on cultivating the students' ability of abstract thinking. Reasonable moderate use of multimedia teaching to cultivate students' abstract thinking can get twice the result with half the effort. But if too much pursuit images forms of appearance, constantly switching alternately, attract students through content rich and colorful images, as a result the students' attention on the novel and interesting picture, ignore the picture behind the scientific principle and the knowledge system, is not conducive to cultivate students' abstract thinking ability.

(3) Pay more attention to the multimedia teaching process effect do not meet the requirements of quality education. Quality education is a comprehensive improve the basic quality of people as the fundamental purpose, to respect the person's subjectivity and initiative, on the basis of human personality, pay attention to the wisdom of the exploitation of the potential, pay attention to the form of sound personality is a fundamental feature of education. Develop students' English listening ability, not only need to study hard and you also need to teacher's guidance and training. Too much attention to the multimedia teaching process, and even students use the tape instead of reading, the students' pronunciation, intonation and pronunciation errors is not correct, also affects the students' listening and speaking skills. English teaching to cultivate students' listening, speaking, reading, writing and translating "and other comprehensive ability can carry on mainly through the classroom teaching activities and implementation. Design and interactive multimedia teaching due to lack of class, can't achieve to the cultivation of the students' comprehensive ability also will not quality education requirements.

(4) Lack of interaction between teachers and students, and deviated from the essence of the teaching. Teacher is the guide of teaching process, teachers in imparting professional knowledge at the same time, in order to own moral behavior, and charm, through emotional communication to establish a close relationship between teachers and students, the education thought to cause the student, teaching knowledge can be easily accepted by students, more easy to shape the students' perfect personality. Student's attention on the projection screen, busy teachers expression, not from the teacher's body language suggests that teachers can timely understand the students' learning state and degree of understanding of the problem. English teaching is a process of emotional communication between teachers and students multimedia courseware can't replace the guide and encourage teachers in the classroom or criticism. Only through the exchange of information and emotions to English teaching becomes vivid, teacher's tone, gestures and facial expressions will help students experience and understand the English language.

\section{Suggestions of Multimedia Application in College English Teaching}

Aiming at the problem of multimedia college English teaching, this paper puts forward Suggestions as follows:

(1) Realize the combination of traditional teaching method and modern teaching means. Multimedia teaching means to change abstracts concretely as, give full play to the role of the vision and perception, pay attention to cultivate the innovation ability of students; Traditional teaching 
method by teachers explain and textbooks, has certain closed and conservative, but it is good to cultivate the students ability to acquire knowledge. The development of information technology makes the traditional teaching method has received the unprecedented challenge, but in the process of our development highlights the lack of modern teaching methods. Information technology to help the teacher who is good at play to the advantages of work, make teachers have more time to deal with more important teaching work; The traditional teaching can solve problems at any time in the students' learning and face-to-face emotional communication between teachers and students. From the dialectical point of view, the traditional teaching method with modern teaching methods having their own advantages and disadvantages. Therefore, both neither entirely replace, also can't repel each other, but to achieve organic integration of traditional teaching method and modern teaching means, avoid their inadequacy, play to their respective advantages, can produce incomparable effect, have very good prospects.

(2) Pay attention to the practicability of multimedia courseware. Multimedia courseware is a kind of auxiliary teaching means, can't replace teachers' guiding role and students' main body function, design and production should with practical give priority to. To make courseware, avoid capacity is too big, not to replace the interaction between teachers and students English teaching idea, don't make English teachers into the computer operator. Students passively watching for a long time also easy to produce visual fatigue and psychological fatigue even tired of psychology. Therefore, under the requirements of the teaching, pay attention to the content is right amount, at a moderate speed. On the choice of material should choose as far as possible to visualize the dynamic material, reduce the number of words. Text and background color contrast, page should overall color is simple the whole courseware style is unified. In college English teaching, the multimedia teaching courseware is often used in the following part: introduce the cultural background, the author and the character information and so on, in order to extend the vivid image information, the use of multimedia courseware of audio, video and photos, etc., show, many forms and to make the students easy to accept, avoid boring.

(3) Avoid make English lesson of multimedia courseware. Using computer multimedia auxiliary teaching reasonably is to improve the efficiency of English classroom teaching. However, if the deliberate pursuit of modernization, excessive use of multimedia, English lessons will be turned into a demonstrative lesson of multi-media coursewares, teachers become "projectionist" role. Would take the role of teachers in the English classroom blindly pursue the display of multimedia teaching courseware, it should be the teacher tells the content into a multimedia presentation. Put in a specific context of emotional communication between teachers and students, to t2dm information interaction; Between the students and teachers, students and students of oral communication, man-machine dialogue must be clearly aware that English is a practical subject and the language must pass between teachers and students and between students and students in large quantities by using English communication, to cultivate the real English communication skills. Teachers should adjust the students' attention in the teaching process, and in a timely manner to correct the problems, teachers play the leading role and the auxiliary function of multimedia.

(4) Follow the principle of Meyer multimedia design. Richard e. Mayer is a famous education psychology and cognitive psychologists, main study is how to study and how to help people study, namely in learning, dialogue between science and the teaching of science cognition, teaching and cross links between technology, based on cognitive science theory about how people learn. Mayer proposed related to design online teaching of multimedia learning cognitive theory, puts forward the eight 12 multimedia learning and teaching principles, as shown in Table 1. Multimedia college English teaching must also follow these rules. 
Table 1. Meyer's principle of multimedia design

\begin{tabular}{|c|c|c|}
\hline No & Principle Name & Principle Explain \\
\hline 1 & $\begin{array}{l}\text { Multimedia } \\
\text { principle }\end{array}$ & $\begin{array}{l}\text { Use a large number of text also to describe the content is clear, but more } \\
\text { can use of words and images to improve the students' learning. }\end{array}$ \\
\hline 2 & $\begin{array}{l}\text { Contiguity } \\
\text { principle }\end{array}$ & $\begin{array}{l}\text { It includes space and time nearby. Space nearby, the corresponding text } \\
\text { and graphics on the screen are close apart, it is better to learn; Time is } \\
\text { nearby, the corresponding text and graphics rendering at the same time, it } \\
\text { is better to learn. }\end{array}$ \\
\hline 3 & $\begin{array}{l}\text { Modality } \\
\text { principle }\end{array}$ & $\begin{array}{l}\text { Composed of animation and multimedia present and learning by the } \\
\text { animation of the screen text and multimedia learning effect is better. }\end{array}$ \\
\hline 4 & $\begin{array}{l}\text { Redundancy } \\
\text { principle }\end{array}$ & $\begin{array}{l}\text { Composed of animation and rendering material, than by the animation, the } \\
\text { explanation of the screen text and present material can obtain a better } \\
\text { result. }\end{array}$ \\
\hline 5 & $\begin{array}{l}\text { Coherence } \\
\text { principle }\end{array}$ & $\begin{array}{l}\text { Irrelevant material will be distracted, hinder the connection between the } \\
\text { building materials, the temptation to study other content. Multimedia } \\
\text { remove irrelevant sounds, pictures and text materials, such as learning } \\
\text { effect will be better. }\end{array}$ \\
\hline 6 & $\begin{array}{l}\text { Signaling } \\
\text { principle }\end{array}$ & $\begin{array}{l}\text { When add clues to highlight the basic material of multimedia information } \\
\text { organization, learning effect will be better, the learner's cognitive burden. }\end{array}$ \\
\hline 7 & $\begin{array}{l}\text { Segmenting } \\
\text { principle }\end{array}$ & $\begin{array}{l}\text { When multimedia information according to the learner's progress appears } \\
\text { in the form of fragments, than in the form of a continuous unit show the } \\
\text { effect is good. }\end{array}$ \\
\hline 8 & $\begin{array}{l}\text { Pre-training } \\
\text { principle }\end{array}$ & $\begin{array}{l}\text { When learners know the name of the main concepts and characteristics in } \\
\text { advance, can achieve better effect in multimedia learning. }\end{array}$ \\
\hline 9 & $\begin{array}{l}\text { Personalization } \\
\text { principle }\end{array}$ & $\begin{array}{l}\text { When multimedia presentation of language based on the style of } \\
\text { conversation rather than an informal style, study will be more in-depth. }\end{array}$ \\
\hline 10 & Voice principle & $\begin{array}{l}\text { When multimedia information issued the language in a standard accent } \\
\text { vocals rather than a machine voice or foreign accent when vocals, more } \\
\text { in-depth study. }\end{array}$ \\
\hline 11 & Image principle & $\begin{array}{l}\text { When present in the multimedia speakers image appeared on the screen, } \\
\text { not necessarily can bring better effect than not. }\end{array}$ \\
\hline
\end{tabular}

\section{References}

[1] J. Zang, "A Research on the Problem Analysis and Countermeasures of Multimedia Network Teaching in Colleges and Universities," Jiangsu Education Research, vol. 33, no. 12, pp. 30-33, 2016.

[2] H. X. Shan, "The advantages of applying multimedia teaching methods in English Teaching," http://blog.sina.com.cn/s/blog_7ece20930100rahr.html, 2016-10-22.

[3] J. Xiong, "How to realize the effective English classroom teaching under the multimedia teaching," http://www.5ykj.com/Article/jxlwyylw/107129.htm, 2016-10-22.

[4] Y. F. Hu, "Exploration into making and use of multimedia English teaching courseware," Journal of University of Science and Technology Liaoning, vol. 31, no. 3, pp. 411-413, 2008.

[5] L. Zhang, Q. L. Sheng, "How Technology Should Be Committed to the Promotion of Learning: Mayer's View on Multimedia Learning and Teaching Designing," Journal of Distance Education, vol. 27, no. 2, pp. 26-32, 2009.

[6] 3Sina blog, "A brief introduction to Meyer's cognitive view on Multimedia Learning," http://blog.sina.com.cn/s/blog_b45a1af8010193ua.html, 2016-10-22. 
[7] langfly Engiish, "The influence of multimedia in English Teaching," http://www.langfly.com/a/20100304/093738.shtml, 2016-10-22.

[8] W. W. Wang, "Problems and Countermeasures of Multimedia English Teaching in Colleges and Universities," The Chinese Journal of ICT in Education, vol. 22, no. 14, pp. 56-56, 2016. 